\title{
Pengaruh Berita Hoaks Terhadap Persepsi Pembaca Media Online (Pemberitaan Ratna Sarumpaet di Media Kumparan)
}

\author{
Berllin Ahnes Ovita Yanti, Farid Rusdi \\ Berlin.915150192@stu.untar.ac.id,farid@fikom.untar.ac.id
}

Fakultas Ilmu Komunikasi Universitas Tarumanagara

\begin{abstract}
The research is discuss about the effect of hoax news on readers' perceptions of online media. This study uses a quantitative approach and the research method is a survey. The data is collected from questionaire with likert scale. The result of validity test by every declaration from valid respective variable with the value of corrected item-total correction more than 0.20 by means of SPSS 16 calculation. T test obtain significant value at the effect of $x$ variable (Ratna Sarumpaet News) toward Y variable (Perception) that is 0,000 $<0,05$ it means that the effect of $X$ variable toward $Y$ variable has signified and explicit. The square $R$ 0,602 it means the ability of $(X)$ Variable Ratna Sarumpaet News explains that $(Y)$ Variable Perception is amounts 60,2\% whereas the residue is 39,8\% is described by the other factors that is not described in this research. The conclusion from this research, there is the Effect Perception of @ kumparancom Followers on Instagram concerning hoax news of Ratna Sarumpaet News on Kumparan.
\end{abstract}

Keywords: News, Kumparan Media, Perception

\begin{abstract}
Abstrak
Penelitian ini membahas mengenai pengaruh berita hoaks terhadap persepsi pembaca media online. Pemberitaan yang diangkat yakni terkait Ratna Sarumpaet di media online Kumparan. Penelitian ini menggunakan pendekatan kuantitatif dan metode survei. Pengumpulan sampel menggunakan teknik Sampling Non-Random. Data dikumpulkan dengan penyebaran kuisioner dengan skala Likert. Hasil uji validitas dari masing-masing variabel dinyatakan valid dengan nilai Corrected item-total correlation lebih dari 0.2 melalui perhitungan SPSS 16. R square 0,602 yang berarti kemampuan Variabel (X) Pemberitaan Ratna Sarumpaet dalam menjelaskan variabel (Y) persepsi sebesar 60,2\% sedangkan sisanya diperoleh 39,8\% adalah faktor lain yang tidak dijelaskan dalam penelitian ini. Kesimpulan dari penelitian ini ialah adanya pengaruh persepsi terhadap pemberitaan ratna sarumpaet mengenai berita hoaks di media Kumparan.
\end{abstract}

Kata Kunci: Pemberitaan, Media Kumparan, Persepsi

\section{Pendahuluan}

Pada era digital terjadi perubahan teknologi salah satunya adalah munculnya konvergensi media baik media massa konvensional (televisi, radio dan surat kabar) maupun digital. Semakin berkembangnya teknologi pada tahun 2000 muncul internet yang mempermudah seseorang dalam mendapatkan informasi dengan murah dan cepat diakses. Internet menjadi salah satu awal kemudahan dalam melakukan komunikasi. New media membawa pengaruh di masyarakat. Dalam bidang ini banyak menjadi perhatian masyarakat misalnya saja berbagai macam jejaring sosial yang sekarang diminati masyarakat seperti facebook, twitter, skype, yahoo messenger, my space, hello 
dan instagram. Dengan menggunakan jejaring sosial ini dengan mudah dapat menjalin komunikasi dengan semua user di belahan dunia manapun. Televisi, radio dan surat kabar bukanlah termasuk dari new media (https://media.neliti.com/media/publications/224312-konvergensi-media-surat-kabarlokal-stud.pdf)

Perkembangan teknologi ini banyak bermunculan media berita baru yang mana untuk mendobrak industri digital di Indonesia salah satunya adalah media Kumparan. Media ini mengklaim dirinya sebagai platform media yang kolaboratif dan interaktif yang dibangun melalui inovasi dan teknologi terkini. Menurut situs mereka, Kumparan menjunjung tinggi kredibilitas dan memegang teguh etika jurnalisme.Terlepas dari etika jurnalisme, ternyata masih banyak terdapat berita bohong (hoaks) yang selalu meresahkan publik, Meski terbilang baru masuk ke Indonesia, berita hoaks sebenarnya memiliki sejarah tersendiri. Kabar kebohongan bisa disebut hoaks apabila dibuat secara sengaja agar dipercaya sebagai kepercayaan, dan dapat mempengaruhi opini publik.diakses : https://lifeat.kumparan.com/index

Sebagai media kolaboratif dan interaktif, kumparan memberitakan berita Ratna Sarumpaet ini, berita tersebut di anggap sebagai berita hoaks karena tidak dapat dipastikan kebenarnnya. Hal tersebut banyak terjadi pro dan kontra dari pembaca berita dikumparan salah satunya di Instagram @kumparancom. Pada saat pemberitaan ini banyak pembaca dari kumparan melakukan respon dan persepsi terhadap kasus tersebut karena hal tersebut dikaitkan pada politik yang pasalnya Ratna Sarumpaet merupakan salah satu pendukung dari Prabowo-Sandi sehingga pemberitaan tersebut menjadi banyak direspon oleh publik mengenai berita hoaks yang dilakukan oleh Ratna Sarumpaet.Adapun alasan penulis menggunakan media kumparan sebagai penelitian ialah karena media kumparan tidak menganggap teknologi sebagai pilar pendukung, melainkan sebagai fondasi utama dan meskipun terbilang media baru di Indonesia Kumparan mampu menyaingi media berita lainnya terbukti dari followers Instagram kumparancom yang dapat menyaingi media Instagram lainnya. Sehingga penulis ingin mengetahui seberapa besar Pengaruh berita hoaks terhadap persepsi pembaca media online (Pemberitaan Ratna Sarumpaet di Media Kumparan).

\section{Metode Penelitian}

Penelitian ini menggunakan pendekatan kuantitatif, Menurut Sugiyono (2011) pengertian dari metode penelitian kuantitatif ialah metode penelitian yang berlandaskan pada filsafat postitivisme, digunakan untuk meneliti pada populasi atau sampel tertentu, teknik pengambilan sampel pada umunya dilakukan secara random, pengumpulan data menggunakan instrument penelitian, analisis data bersifat kuantitatif/statistik dengan tujuan untuk menguji hipotesis yang telah ditetapkan. Metode pada penelitian ini ialah deskriptif kuantitatif, populasi pada penelitian ini ialah followers dari akun Instagram Kumparancom yang berjumlah 263.000 pengikut. Jumlah sampel yang digunakan dalam penelitian ini jumlah 100. 
Berllin Ahnes Ovita Yanti, Farid Rusdi: Pengaruh Berita Hoaks Terhadap Persepsi Pembaca Media Online (Pemberitaan Ratna Sarumpaet di Media Kumparan)

Tabel 1. Operasional Konsep Penelitian

\begin{tabular}{|c|c|c|c|}
\hline Variabel & Dimensi & Indikator & Skala \\
\hline \multirow{4}{*}{$\begin{array}{l}\text { Pemberitaan di } \\
\text { media } \\
\text { Kumparan } \\
\text { Variabel }(\mathrm{X})\end{array}$} & Frekuensi & $\begin{array}{ll}\text { - } & \text { Frekuensi mengakses berita di media dalam } \\
\text { seminggu } \\
\text { - }\end{array}$ & Likert \\
\hline & Durasi & 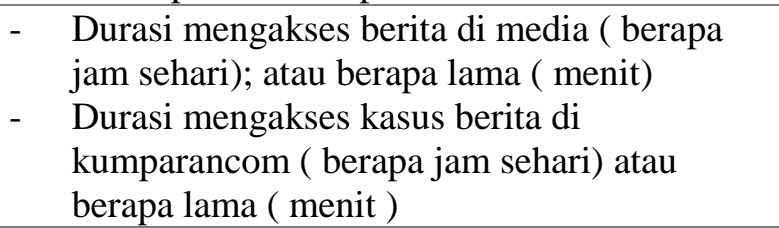 & Likert \\
\hline & Isi pesan & $\begin{array}{l}\text { - Isi pesan yang disampaikan oleh media } \\
\text { - Isi pesan dalam memahami suatu berita di } \\
\text { media } \\
\text { - Isi pesan merupakan kebenaran dan tidak } \\
\text { dilebih-lebihkan oleh media } \\
\text { - Isi pesan tidak megandung opini negative }\end{array}$ & Likert \\
\hline & Daya tarik & $\begin{array}{l}\text { - Media berita memiliki ciri khas untuk menarik } \\
\text { perhatian khalayak } \\
\text { - Konsep suatu berita sangat menarik untuk } \\
\text { dibaca dan mudah dipahami } \\
\text { - Suatu berita tersebut menarik untuk dibaca } \\
\text { - Unggahan foto dari seuatu berita membuat } \\
\text { khalayak tertarik } \\
\text { - Suatu berita tersebut memiliki dampak bagi } \\
\text { khalayak }\end{array}$ & Likert \\
\hline \multirow{3}{*}{$\begin{array}{l}\text { Persepsi publik } \\
\text { terhadap } \\
\text { pemberitaan } \\
\text { ratna sarumpaet } \\
\text { Variabel (Y) }\end{array}$} & Sensasi & $\begin{array}{l}\text {-Tulisan berita menarik untuk dibaca } \\
\text {-Kualitas suatu berita hoaks di media } \\
\text { - Berita dan ilustrasinya sangat menarik untuk } \\
\text { dibaca } \\
\text { - penyajian berita beserta ilustrasi membuat saya } \\
\text { tertarik untuk membaca } \\
\text { - Berita dan ilustrasi sangat mudah untuk } \\
\text { dipahami } \\
\text { - Suatu berita tersebut adalah hal yang paling } \\
\text { viral di publik } \\
\text { - Laman berita menarik dan mudah untuk di } \\
\text { akses }\end{array}$ & ikert \\
\hline & Atensi & $\begin{array}{l}\text { - Berita di media tersebut menarik perhatian } \\
\text { untuk mengetahui lebih lanjut } \\
\text { - Berita di media tersebut membuat saya } \\
\text { mengabaikan berita media lainnya } \\
\text { - Berita tersebut membuat saya ingin mengetahui } \\
\text { hal lain dari berita tersebut } \\
\text { - Selain media tersebut ada media lain yang saya } \\
\text { baca untuk mengetahui berita tersebut } \\
\text { - Berita tersebut membuat saya berhati - hati } \\
\text { dalam membaca judul bersifat menyimpang }\end{array}$ & Likert \\
\hline & Interpretasi & $\begin{array}{l}\text {-Individu dapat menafsirkan berita tersebut } \\
\text { dengan baik } \\
\text { - Individu dapat menafsirkan judul suatu berita } \\
\text { dengan baik }\end{array}$ & Likert \\
\hline
\end{tabular}



- Individu dapat menafsirkan isi suatu berita dengan baik
- Individu dapat menafsirkan berita hoaks berdasarkan judul yang di baca
- Indivdu dapat menafisrkan media tersebut merupakan media yang netral/adil
- Individu dapat menafsirkan media tersebut sebagai sumber media berita yang terpacaya

\section{Hasil Temuan dan Diskusi}

\section{Uji Validitas}

Pada penelitian ini, peneliti melakukan uji validitas untuk masing-masing instrumen pertanyaan. Pengujian validitas menyatakan bahwa butir pertanyaan valid atau tidak valid dengan patokan 0,2 dan dibandingkan angka-angka yang ada pada corrected item-Total correlation. Penyebaran kuisioner melalui google form dan penarikan sampel dari followers Instagram kumparan menjadi 100 responden dari pembaca berita di kumparan.

a) Butir pertanyaan variabel $\mathrm{X}$

Tabel 2. Uji Validitas Butir Pertanyaan Variabel X

\begin{tabular}{lrrrr}
\hline & \multicolumn{5}{c}{ Item-Total Statistics } \\
\hline & $\begin{array}{c}\text { Scale Mean if } \\
\text { Item Deleted }\end{array}$ & $\begin{array}{c}\text { Scale Variance if } \\
\text { Item Deleted }\end{array}$ & $\begin{array}{c}\text { Corrected Item-Total } \\
\text { Correlation }\end{array}$ & $\begin{array}{c}\text { Cronbach's Alpha } \\
\text { if Item Deleted }\end{array}$ \\
\hline $\mathrm{x} 1$ & 41.8667 & 75.361 & .720 & .900 \\
\hline $\mathrm{x} 2$ & 41.7333 & 76.133 & .723 & .900 \\
\hline $\mathrm{x} 3$ & 41.8000 & 77.821 & .643 & .903 \\
\hline $\mathrm{x} 4$ & 41.4000 & 77.145 & .697 & .901 \\
\hline $\mathrm{x} 5$ & 40.7667 & 77.840 & .760 & .898 \\
\hline $\mathrm{x} 6$ & 40.8667 & 79.913 & .669 & .902 \\
\hline $\mathrm{x} 7$ & 41.0000 & 80.828 & .599 & .905 \\
\hline $\mathrm{x} 8$ & 41.2667 & 85.995 & .290 & .918 \\
\hline $\mathrm{x} 9$ & 40.8000 & 86.372 & .433 & .911 \\
\hline $\mathrm{x} 10$ & 40.8667 & 84.464 & .554 & .907 \\
\hline $\mathrm{x} 11$ & 40.9667 & 80.999 & .642 & .903 \\
\hline $\mathrm{x} 12$ & 40.8000 & 78.372 & .721 & .900 \\
\hline $\mathrm{x} 13$ & 41.0667 & 77.444 & .766 & .898 \\
\hline
\end{tabular}

Sumber: Hasil Pengolahan Data SPSS 16

Seperti yang terlihat pada tabel 4.35 seluruh instrumen pertanyaan pada kuisioner dari variabel x yaitu "Pemberitaan Ratna Sarumpaet" memiliki nilai lebih dari 0,200 yang artinya memenuhi syarat validitas. 
Berllin Ahnes Ovita Yanti, Farid Rusdi: Pengaruh Berita Hoaks Terhadap Persepsi Pembaca Media Online (Pemberitaan Ratna Sarumpaet di Media Kumparan)

b) Butir pertanyaan variabel Y

Tabel 3. Uji Validitas Butir Pertanyaan Variabel Y

\begin{tabular}{|c|c|c|c|c|}
\hline \multicolumn{5}{|c|}{ Item-Total Statistics } \\
\hline & $\begin{array}{l}\text { Scale Mean if } \\
\text { Item Deleted }\end{array}$ & $\begin{array}{l}\text { Scale Variance if } \\
\text { Item Deleted }\end{array}$ & $\begin{array}{l}\text { Corrected Item-Total } \\
\text { Correlation }\end{array}$ & $\begin{array}{l}\text { Cronbach's } \\
\text { Alpha if Item } \\
\text { Deleted }\end{array}$ \\
\hline y1 & 62.0000 & 174.759 & .861 & .965 \\
\hline $\mathrm{y} 2$ & 62.1333 & 176.051 & .852 & .965 \\
\hline y3 & 62.0000 & 175.034 & .850 & .965 \\
\hline $\mathrm{y} 4$ & 62.0000 & 175.793 & .852 & .965 \\
\hline y5 & 61.7667 & 186.116 & .625 & .968 \\
\hline y6 & 61.7667 & 183.357 & .559 & .969 \\
\hline y7 & 62.1000 & 176.369 & .879 & .965 \\
\hline $\mathrm{y} 8$ & 62.5333 & 178.809 & .645 & .968 \\
\hline y9 & 62.4333 & 175.978 & .806 & .966 \\
\hline $\mathrm{y} 10$ & 61.8667 & 185.085 & .486 & .970 \\
\hline y11 & 61.6333 & 184.309 & .548 & .969 \\
\hline y12 & 62.1333 & 176.189 & .882 & .965 \\
\hline y13 & 62.5333 & 175.913 & .750 & .966 \\
\hline y14 & 62.1333 & 174.947 & .898 & .964 \\
\hline y15 & 62.2000 & 174.097 & .894 & .964 \\
\hline y16 & 62.1333 & 173.913 & .941 & .964 \\
\hline $\mathrm{y} 17$ & 62.0667 & 173.926 & .881 & .965 \\
\hline y18 & 62.0333 & 178.723 & .827 & .965 \\
\hline
\end{tabular}

Sumber: Hasil Pengolahan Data SPSS 16

Seperti yang terlihat pada tabel 4.36 seluruh instrumen pertanyaan pada kuisioner dari variabel Y yaitu "Persepsi" memiliki nilai lebih dari 0,200 yang artinya memenuhi syarat validitas.

\section{Uji Reliabilitas}

Pengujian reliabilitas dilakukan dengan menggunakan uji statistik Cronbach's Alpha, bahwa dimensi dinyatakan reliabel apabila memiliki nilai Cronbach's Alpha lebih dari 0,600. Berikut merupakan hasil uji reliabilitas dari Pemberitaan Ratna Sarumpaet (X) dan Persepsi (Y):

Table 4. Uji Realibitlitas

\begin{tabular}{cccc}
\hline Variabel & N & Cronbach's Alpha & Keterangan \\
& & & \\
\hline $\begin{array}{c}\text { Pemberitaan Ratna Sarumpaet } \\
(\mathrm{X})\end{array}$ & 13 & 0.770 & Reliabel \\
\hline Persepsi (Y) & 19 & 0.768 & Reliabel \\
\hline
\end{tabular}

Sumber: Pengolahan Hasil data SPSS 16

Koefisien Korelasi

Pada tabel 4.38 dapat diketahui bahwa nilai pearson correlation (r) sebesar 0,776 dengan siginifikansi (p) $0,000<0,01$. Berdasarkan data tersebut dapat dikatakan 
hubungan variabel X (Pemberitaan Ratna Sarumpaet) dengan variabel Y (persepsi) terdapat hubungan positif yang kuat.

Tabel 5. Koefisien Korelasi

\begin{tabular}{llrr}
\hline & \multicolumn{2}{c}{ Correlations } & \\
\hline & & $\begin{array}{l}\text { PEMBERITAAN_RA } \\
\text { TNA_SARUMPAET }\end{array}$ & PERSEPSI \\
\hline PEMBERITAAN_RATN & Pearson Correlation & 1 & $.776^{* *}$ \\
\cline { 2 - 4 } A_SARUMPAET & Sig. (2-tailed) & 100 & .000 \\
\cline { 2 - 4 } & $\mathrm{N}$ & $.776^{* *}$ & 100 \\
\hline PERSEPSI & Pearson Correlation & .000 & 1 \\
\cline { 2 - 4 } & Sig. (2-tailed) & 100 & 100 \\
\cline { 2 - 4 } & $\mathrm{N}$ & & \\
\hline
\end{tabular}

**. Correlation is significant at the 0.01 level (2-tailed).

Sumber: Pengolahan data SPSS 16

Koefisien Determinasi

Pada tabel 4.39 diperoleh $\mathrm{R}$ square 0,602 yang berarti kemampuan variabel (X) Pemberitaan Ratna Sarumpaet dalam menjelaskan variabel (Y) persepsi sebesar 60,2\% sedangkan sisanya diperoleh $39,8 \%$ dijelaskan oleh faktor-faktor lain yang tidak dijelaskan dalam penelitian ini.

Tabel 6. Uji Determinasi

\begin{tabular}{lcrrr}
\hline Model & R & R Square & Adjusted R Square & $\begin{array}{c}\text { Std. Error of the } \\
\text { Estimate }\end{array}$ \\
\hline 1 & $.776^{\mathrm{a}}$ & .602 & .598 & 8.72599 \\
\hline
\end{tabular}

a. Predictors: (Constant), PEMBERITAAN_RATNA_SARUMPAET

Sumber: pengolahan hasil data SPSS 16

Analisis Regresi Linier Sederhana

Tabel 7. Uji Analisis Regresi Linier Sederhana

\begin{tabular}{|c|c|c|c|c|c|c|}
\hline \multicolumn{7}{|c|}{ Coefficients $^{\mathrm{a}}$} \\
\hline \multirow{2}{*}{\multicolumn{2}{|c|}{ Model }} & $\begin{aligned} \text { Unstal } \\
\text { Coef }\end{aligned}$ & $\begin{array}{l}\text { dardized } \\
\text { icients }\end{array}$ & $\begin{array}{c}\text { Standardize } \\
\mathrm{d}\end{array}$ & $\mathrm{t}$ & Sig. \\
\hline & & B & Std. Error & Beta & & \\
\hline \multirow[t]{2}{*}{1} & (Constant) & 23.951 & 3.632 & & 6.595 & .000 \\
\hline & $\begin{array}{l}\text { PEMBERITAAN_RAT } \\
\text { NA_SARUMPAET }\end{array}$ & .964 & .079 & .776 & 12.169 & .000 \\
\hline
\end{tabular}

a. Dependent Variable: PERSEPSI

Sumber: pengolahan hasil data SPSS 16

Berdasarkan hasil pengolahan data SPSS 16 pada tabel 4.40 diperoleh nilai konstanta a sebesar 23.951, yang artinya jika tidak ada kenaikan Pemberitaan Ratna Sarumpaet. Maka persepsi akan mencapai 23.951, sedangkan nilai konstanta b sebesar 
0,964 yang menunjukkan setiap ada penambahan nilai untuk 1 Pemberitaan Ratna Sarumpaet, maka ada kenaikan persepsi 0,964. Apa bila dimasukkan rumus maka $Y=$ 23,951+ 0,964X, dengan X adalah Pemberitaan Ratna Sarumpaet dan Y adalah Persepsi.

Uji t

Berdasarkan tabel 4.40 hasil penelitian dari 100 responden diperoleh nilai signifinkansi pada pengaruh variabel $\mathrm{X}$ (Pemberitaan Ratna Sarumpaet) terhadap variabel $\mathrm{Y}$ ( Persepsi) adalah $0,000<0,05$ yang artinya Pengaruh variabel $\mathrm{X}$ ( pemberitaan) terhadap variabel Y (persepsi) telah signifikan dan jelas. Maka diperoleh kesimpulan bahwa hipotesis kedua (Ha) penelitian ini mendukung adanya pengaruh antara Pemberitaan Ratna Sarumpaet terhadap persepsi followers Instagram @ kumparancom.

\section{Simpulan}

Meskipun followers Instagram @ Kumparancom kadang-kadang membaca kasus Ratna Sarumpaet di media Kumparan lebih dari sekali dalam seminggu, tetapi mereka sangat memahami isi berita yang diberitakan oleh media Kumparan. Terkait berita hoaks Ratna Sarumpaet membuat responden mengabaikan berita lainnya dan juga menjadi lebih berhati-hati dengan judul berita serta isi yang bersifat provokatif.

Berita Hoaks Ratna Sarumpaet mempengaruhi durasi membaca responden terbukit dari hasil pengolahan data pada penelitian ini. Penelitian ini juga membuktikan bahwa pemberitaan ini banyak di respon oleh followers Instagram kumparan bukan karena ia adalah seorang pendukung dari Prabowo dan Sandiaga Uno tapi karena ia adalah seorang aktivis Sosial.

\section{Ucapan Terima Kasih}

Penulis mengucapkan terima kasih kepada pihak-pihak yang telah membantu dalam penelitian ini.

\section{Daftar Pustaka}

Ardianto \& Erdinaya, Lukiati Komala. (2005). Komunikasi massa: Suatu pengantar. Bandung: Simbiosa Rekatama Media

Sugiyono. (2011). Metode Penelitian Kuantitatif, Kualitatif dan R\&D. Bandung: Afabeta

https://kumparan.com/@ kumparannews/polisi-ungkap-ratna-sarumpaet-tak-dianiayatapi-ke-rs-bina-estetika-1538531966179595866?ref=bcjuga (pada 06

Desember 2018, 13.39 WIB)

https://kumparan.com/@kumparannews/ratna-sarumpaet-diduga-dianiaya-dibandung-hingga-babak-belur-1538452956048752333 (pada tanggal 06 Desember 2018, 13:39 WIB

https://lifeat.kumparan.com/index https://media.neliti.com/media/publications/224312-konvergensi-media-surat-kabarlokal-stud.pdf 